УДК 347.965.2

DOI https: / / doi.org/10.32837 / yuv.v0i3.933

\title{
В. Владишевська,
}

асистент кафедри організації судових, правоохоронних органів та адвокатури Національного університету «Одеська юридична академія»

\section{КВАЛІФІКАЦІЙНО-ДИСЦИПЛІНАРНА КОМІСІЯ АДВОКАТУРИ ЯК СУБЕКТ ДОСТУПУ ДО ПРОФЕСІЇ АДВОКАТА}

Постановка проблеми. Високий рівень надання адвокатами професійної правничої (правової) допомоги прямо залежить від забезпечення об'єктивності, гласності та рівності у процесі набуття права на заняття адвокатською діяльністю. Особливої уваги заслуговує питання місця і ролі кваліфікаційно-дисциплінарної комісії адвокатури щодо організації, порядку доступу та оцінювання кваліфікаційного екзамену, як однієї із вимог доступу до професії.

Стан дослідження. Питання набуття права на заняття адвокатською діяльністю було предметом досліджень багатьох вчених-правників, серед яких: С.С. Алєксєєв, А.М. Бірюкова, Н.M. Бакаянова, Т.В. Варфоломеєва, В.В. Гайворонська, С.В. Гончаренко, B.В. Заборовський, О.А. Овсянникова, С.Ф. Сафулько, В.О. Святоцька, О.Д. Святоцький, М.А. Погорецький, Д.П. Фіолевський, І.Я. Фойницький, О.Г. Яновська та інші.. Однак комплексного дослідження участі кваліфікаційно-дисциплінарної комісії адвокатури, як суб'єкта доступу до адвокатської діяльності, здійснено не було.

Метою статті $€$ комплексне дослідження місця й ролі кваліфікаційно-дисциплінарної комісії адвокатури, як суб'єкта доступу до адвокатської діяльності, та внесення пропозиціі щодо удосконалення законодавства про адвокатуру та адвокатську діяльність.

Виклад основного матеріалу. Конституція України гарантує кожному право на професійну правничу (правову) допомогу, делегуючи цю функцію інституту адвокатури. Виключно адвокат здійснює представництво іншої особи в суді, а також захист від кримінального обвинувачення. 3 огляду на це, особливої уваги потребує питання набуття права на заняття адвокатською діяльністю, оскільки від професійності, компетентності та моральності адвоката залежить якість реалізації кожного громадянина такого права.

Питання набуття права на заняття адвокатською діяльністю врегульовано у розділі II Закону України «Про адвокатуру та адвокатську діяльність». Зокрема, в особа, яка виявила бажання стати адвокатом, повинна відповідати вимогам, зазначеним у статті 6 Закону України «Про адвокатуру та адвокатську діяльність», а саме: мати повну вищу юридичну освіту; володіти державною мовою; мати стаж роботи в галузі права не менше двох років; скласти кваліфікаційний іспит; пройти стажування (крім випадків, встановлених Законом); скласти присягу адвоката України; отримати свідоцтво про право на заняття адвокатською діяльністю [1].

3 аналізу положень Закону вбачається, що процедура доступу до професії адвоката виглядає таким чином: 1) особа, яка виявила бажання стати адвокатом, звертається до кваліфікаційно-дисциплінарної комісії адвокатури за місцем проживання із заявою про допуск до складення кваліфікаційного іспиту 2) кваліфікаційно-дисциплінарна комісія адвокатури, перевіривши відповідність особи вимогам, установленим Законом, приймає одне із рішень: допуск особи до кваліфіка- 


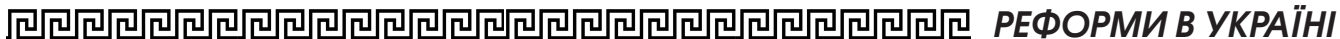

ційного іспиту або відмову в допуску; 3) у разі прийняття позитивного рішення - особа складає кваліфікаційний іспит 4) кваліфікаційно-дисциплінарна комісія адвокатури безоплатно видає свідоцтво про складення кваліфікаційного іспиту особі, яка склала кваліфікаційний іспит, протягом десяти днів 3 дня складення кваліфікаційного іспиту; 5) рада адвокатів регіону видає направлення на проходження стажування; 6) проходження стажування під керівництвом адвоката-керівника стажування; 7) за результатами стажування керівник стажування складає звіт про оцінку стажування та направляє його раді адвокатів регіону; 8) за оцінкою результатів стажування рада адвокатів регіону приймає рішення про видачу особі свідоцтва про право на заняття адвокатською діяльністю або про продовження стажування на строк від одного до трьох місяців; 9) особа, стосовно якої радою адвокатів регіону прийнято рішення про видачу свідоцтва про право на заняття адвокатською діяльністю, не пізніше тридцяти днів з дня прийняття цього рішення складає перед радою адвокатів регіону присягу адвоката України; 10) особі, яка склала присягу адвоката України, радою адвокатів регіону у день складення присяги безоплатно видаються свідоцтво про право на заняття адвокатською діяльністю та посвідчення адвоката України.

Особливий науковий та практичний інтерес становлять питання допуску, організації та оцінювання кваліфікаційного іспиту. Організація та проведення кваліфікаційного іспиту здійснюється кваліфікаційною палатою кваліфікаційно-дисциплінарних комісій адвокатури регіонів. У свойй діяльності кваліфікаційно-дисциплінарні комісії керуються засадами відкритості, гласності, законності, незалежності, об'єктивності, колегіальності прийняття рішень та їх обов' язковість[2].

Принагідно відзначити, що члени кваліфікаційно-дисциплінарної комісії адвокатури обираються конференцією адвокатів регіону з числа адвокатів, стаж адвокатської діяльності яких становить не менше п'яти років та адреса робочого місця яких знаходиться відповідно в Автономній Республіці Крим, області, місті Києві, місті Севастополі і відомості про яких включено до Єдиного реєстру адвокатів України, строком на п'ять років. До прикладу, у Польщі адвокатський (екзаменаційний) іспит проводиться екзаменаційними комісіями $з$ стажування при Міністрі Юстиції. Членів екзаменаційних комісій призначають із спеціалістів в галузі права, задіяних в іспиті, знання та досвід яких $є$ запорукою справедливого перебігу іспиту [3].

У Російській Федераціі кваліфікаційний іспит для отримання права на заняття адвокатською діяльністю організовується та проводиться кваліфікаційною комісією адвокатської палати. Кваліфікаційна комісія формується в кількості 13 членів комісії за такими нормами представництва: 7 адвокатів від адвокатської палати (за умови наявності стажу роботи не менше 5 років), 2 представника від територіального органу юстиції, 2 представники від законодавчого органу державної влади, 2 суддів [4].

Допуск до професії адвоката в Азербайджанській республіці здійснює Кваліфікаційна комісія Колегії адвокатів (див. розділ I) [5]. Кваліфікаційна комісія здійснює діяльність у складі дев'яти членів, включаючи трьох адвокатів, суддів і вчених-правознавців. Адвокати - члени кваліфікаційної комісії призначаються, відповідно, президією колегії адвокатів, судді - члени цієї комісії - Верховним судом Азербайджанської Республіки, інші три члена кваліфікаційної комісії, які $€$ вченими-правознавцями, призначаються відповідним органом виконавчої влади.

В цьому контексті слід зауважити, що за радянських часів в Українській PCР питанням визначення рівня професійних знань осіб, які мали намір займатися адвокатською діяльністю, займались атестаційні палати ква- 


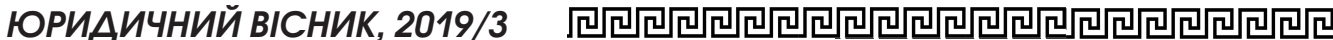

ліфікаційно-дисциплінарних комісій адвокатури. Формування таких комісій здійснювалось не тільки за участі адвокатів (атестаційна палата утворювалась у складі 11 членів, серед яких: 4 адвокати, 4 судді та по одному представнику від Ради Міністрів Республіки Крим, обласної, Київської і Севастопольської міських Рад народних депутатів, управління юстиції Ради Міністрів Республіки Крим, обласної, Київської і Севастопольської міської державної адміністрації, відділення Спілки адвокатів України) [6], тобто вказану структуру навряд чи можна було назвати адвокатським самоврядуванням.

Як зазначають окремі науковці, адвокатський корпус може формуватися виключно самими ж адвокатами. Це, безумовно, власне і відноситься до традицій адвокатури. Інший спосіб формування адвокатського корпусу допускає участь у цьому процесі осіб, що не є адвокатами. Це так звані представники громадськості - наукові та педагогічні працівники в галузі права, депутати законодавчих органів. У цьому варіанті можна знайти раціональне зерно, якщо вважати таких неадвокатів представниками громадянського суспільства. Але ці люди можуть висловлювати лише сторонню думку про доцільність прийняття в адвокати кандидатів, тобто мати право дорадчого голосу [7, с.276]. 3 цього приводу справедливо відзначає Н. Анікіна той факт, що: «виключно адвокати, можуть краще за інших оцінити знання претендента, зрозуміти, чи відповідає особа вимогам, які необхідні для здійснення адвокатської діяльності, чи зможе вона на високому професійному рівні надавати правову допомогу [8, с.288].

В цьому аспекті Д.П. Фіолевський слушно відмічає, що: «Закон України «Про адвокатуру та адвокатську діяльність» значно підвищив статус адвокатури шляхом подальшої демократизації цього інституту в Україні та суттєвого посилення іi незалежності. Одним з радикальних кроків $є$ виведення ква- ліфікаційно-дисциплінарних комісій 3-під контролю виконавчої влади і передача функції формування самоврядних органів адвокатури в руки самих адвокатів» [9, с. 269].

Першим кроком на шляху до реалізаціі права на отримання статусу адвоката $є$ звернення до кваліфікаційно-дисциплінарної комісії адвокатури регіону за місцем проживання із заявою про допуск до складення кваліфікаційного іспиту. Разом із заявою слід подати письмову згоду на обробку персональних даних, проведення перевірки повноти та достовірності повідомлених відомостей та ряд документів (зокрема, про підтвердження набуття вищої освіти, про стаж роботи в галузі права, про реєстрацію місця проживання, тощо). Вирішення питання про допуск до складення кваліфікаційного іспиту приймається на засіданні КДКА без участі заявника. За результатами розгляду заяви та доданих до неї документів кваліфікаційно-дисциплінарна комісія адвокатури приймає одне із таких рішення: про допуск особи до складення кваліфікаційного іспиту, або про відмову в допуску особи до складення кваліфікаційного іспиту.

Особа, стосовно якої прийнято рішення про допуск до складення кваліфікаційного іспиту, у встановлений КДКА строк, але, у будь-якому випадку не пізніше дня, що передує даті складення кваліфікаційного іспиту, зобов"язана внести на банківський рахунок комісії плату за складення кваліфікаційного іспиту, у розмірі, встановленому Радою адвокатів України. На виконання вказаних вимог Радою адвокатів України було прийнято Рішення «Про встановлення плати за складання кваліфікаційного іспиту» від 03.02.2017 р. №5 та встановлено плату за складання кваліфікаційного іспиту у розмірі трьох прожиткових мінімумів для працездатних осіб, установлених законом на день подання особою заяви про допуск до складання кваліфікаційного іспиту. На сьогоднішній день ця сума становить 5763 грн. 


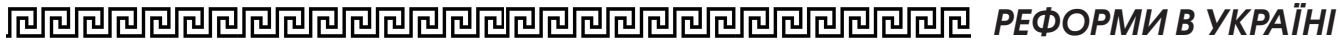

Слід визнати таким, що відповідає принципам організації й діяльності адвокатури, встановлення плати за складення кваліфікаційного іспиту та направлення цих коштів на фінансування адвокатури. При цьому адвокатська спільнота реалізує право на самостійне визначення шляхів вирішення потреб адвокатури, не порушуючи права й свободи інших осіб, зокрема тих, хто виявив намір вступити в адвокатську корпорацію [10].

Кваліфікаційний іспит складається 3 двох частин: письмового іспиту та усного іспиту, який полягає у виявленні теоретичних знань у галузі права, історії адвокатури, адвокатської етики особи, яка виявила бажання стати адвокатом, а також у виявленні рівня їі практичних навичок та умінь у застосуванні закону. Після успішного складення кваліфікаційного іспиту претендент в адвокати отримує свідоцтво про складення кваліфікаційного іспиту, яке дійсне протягом трьох років з дня складення іспиту.

3 огляду на те, що метою кваліфікаційного іспиту є, в першу чергу, перевірка претендента на заняття адвокатською діяльністю практичних навичок та вмінь правильно застосовувати закон, пропонується запровадити наступний порядок проходження стажування: складання вступного іспиту на адвокатське стажування, власне стажування та складання кваліфікаційного іспиту. За результатами вступного іспиту можливо реально оцінити реальний рівень теоретичної підготовки майбутнього адвоката, правильно скласти індивідуальний план та програму проходження стажування 3 урахуванням «сильних та слабких сторін» кожного претендента, щоб як слід підготувати його до майбутньої професії. Після успішного складення вступного іспиту, проходження стажування, доцільно складати кваліфікаційний іспит, як кінцевий етап допуску до заняття адвокатською діяльністю. Саме така черговість зробить можливим оцінити на кваліфікаційному іспиті знання та навички, необхідні адвокату, здобуті під час проходження стажування. Доречно зауважити, що така практика існує, до прикладу, в Польщі, Республіці Білорусь та Молдові.

Конституиія України закріплюе право кожного на професійну правничу допомогу, делегуючи ию функцію інституту адвокатури. Для формування високоморальних та професійних представників адвокатської спільноти має суттеве значення забезпечення законності, прозорості, відкритості, рівності усіма суб'єктами та на всіх етапах доступу до адвокатської діяльності.

Автором здійснено порівняльно-правове дослідження правового статусу учасників процедури набуття статусу адвоката, які наділені відповідним комплексом прав, обов'язків та повноважень щодо забезпечення та реалізації права на доступ до професії адвоката в Україні та в країнах пострадянського npocmopy.

Одним із органів адвокатського самоврядування, який безпосередньо бере участь у формуванні кадрового складу адвокатури, є кваліфікаційно-дисичиплінарна комісія адвокатури. Таким чином, статтю присвячено комплексному дослідженню питання місия $і$ ролі кваліфікаиійно-дисциплінарної комісії адвокатури у світлі набуття права на заняття адвокатською діяльністю. Проаналізовано чинне законодавство в частині достуnу до професї адвоката, порядку організації, складення та оцінювання кваліфікаційного іспиту для набуття права на заняття адвокатською діяльністю в Україні.

Метою статті $є$ комплексне дослідження місия й ролі кваліфікаційно-дисциплінарної комісї̈ адвокатури, як суб'єкта доступу до адвокатської діяльності в Україні та аналогічних органів адвокатського самоврядування країн пострадян- 
ського простору, серед яких: Азербайджанська Республіка, Російська Федерація.

На основі вивчення зарубіжного досвіду автором надано пропозиціi щодо вдосконалення законодавства про адвокатуру та адвокатську діяльність щзоо порядку допуску до складення кваліфікаційного іспиту, складення изього іспиту та ойінювання результатів складення кваліфікациійного іспиту для набутmя права на заняття адвокатською діяльністю.

Ключові слова: набуття права на заняття адвокатською діяльністю, кваліфікаційно-дисциплінарна комісія адвокатури, кваліфікаційний іспит, доступ до адвокатської діяльності, органи адвокатського самоврядування.

\section{Vladyshevska V. QUALIFICATION AND DISCIPLINARY COMMISSION OF THE BAR AS AN ACCESS SUBJECT TO THE ATTORNEYSHIP}

The Constitution of Ukraine enshrines everyone's right to professional legal help by delegating this function to the institute of advocacy. It is important to ensure the legality, transparency, openness, equality of all the entities and at all stages of access to advocacy to form high-moral and professional representatives of the advocacy community. The author carried out a comparative legal study of the legal status of participants of the procedure of obtaining the status of a lawyer, who are endowed with an appropriate set of rights, duties and powers to secure and exercise the right to access the lawyer's profession in Ukraine and in the countries of the former Soviet Union.

One of the bodies of attorney self-government, which is directly involved in the formation of the staff of the Bar, is the Qualification and Disciplinary commission of the Bar. Thus, the article is devoted to a comprehensive study of the issue of the place and role of the qualification and disciplinary commission of the Bar in the light of the acquisition of the right to practice law. The current legislation is analyzed in terms of access to the profession of lawyer, procedure of organization, conducting and passing the qualification exam for obtaining the right to practice law in Ukraine.

The purpose of the article is a comprehensive study of the place and role of the qualification and disciplinary commission of the Bar, as a subject of access to advocacy in Ukraine and similar bodies of attorney self-government in the countries of the former Soviet Union, including: Azerbaijan Republic, Russian Federation.

On the basis of studying foreign experience, the author has proposed propositions to improve the legislation on the Bar and Practice of Law, in particular: the procedure for the admission to taking the qualification exam, passing this exam for the person who intends to become an attorney.

The article is devoted to a comprehensive study of the issue of the place and role of the QualificationDisciplinary Commission of the Bar in the context of acquiring of right to practice law. in terms of access to the profession of a lawyer, the procedure for admission, passage and evaluation of the qualification exam to obtain the right to engage in advocacy in Ukraine. The author analyzed the current legislation, foreign experience and made suggestions for improving the legislation on the Bar and Practice of Law.

Key words: the acquisition of the right to engage in advocacy, the Qualification and Disciplinary Commission of the Bar, the qualification exam, access to advocacy, the bodies of attorney selfgovernment.

\section{Література \\ 1. Про адвокатуру та адвокат- ську діяльність: Закон України від}




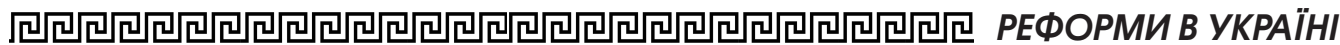

05.07.2012 № 5076-VI // Відомості Верховної Ради України. 2013. № 27. С.1438.

2. Регламент Кваліфікаційно-дисииплінарної комісії адвокатури регіон: Рішення РАУ від від 16 лютого 2013 року №77 із змінами та доповненнями, внесеними рішенням Ради адвокатів України від «14» лютого 2019 року №6. https:// unba.org.ua/assets / uploads / legislation / reglamenti/2019-02-14-reglamenti6_5cee829433e95.pdf;

3. Право на адвокатуру: Закон віо 26 травня 1982 р. $з$ останніми змінами від 23 серпня 2013 р.: /Електронний ресурс/. - Режим доступy:http:// unba.org.ua/assets / uploads / legislations / pologennya/zakonodavstvo-pro-adv-polshazvedenyj-pereklad.pdf;

4. Про адвокатську діяльність та адвокатуру Російської Федерації: Федеральний закон від 31.05 .2002 р.: [Електронний ресурс/. - Режим доступy: http:// www.consultant.ru/document/cons_doc_ LAW_36945;

5. Про адвокатів та адвокатську діяльність: Закон Азербайджанської Республіки від 10 червня 2011 року. /Електронний pecypcl - Режим доступy: http:// шшw. eurasian-advocacy.ru/azerbajdzhanskayarespublika,

6. Про адвокатуру: Закон України від 19.02.1992 р.: [Електронний ресурс]. Pежим docmyny: https://zakon.rada.gov. ua/laws / show / 2887-12,

7. Бакаянова Н.М. Функціональні та оганізиійні основи діяльності адвокатури: дис. ... докт. юрид. наук : 12.00.10 Бакаянова Нана Мезенівна ; . НУ «ОЮА» Одесса, 2018. - 487c.;

8. Анікіна Н. Набуття права на заняття адвокатською діяльністю за новим Законом України «Про адвокатуру та адвокатську діяльність» / Н. Анікіна // Вісник Львівського університету. Серія юридична. - 2014. Bun. 60. - C. 285-290;

9. Фіолевський Д. П Адвокатура: підручник. Вид. 3-тє, випр. i допов. - К. : Правова єдність, 2014. 622 с.;

10. Фінансування органів адвокатського самоврядування у світлі українського та міжнародного досвіду / Н. М. Бакаянова / / Альманах міннародного права. 2015. - Bun. 8. - C. 65-72. - Режuм docmyny: http: / / nbuv.gov.ua / UJRN / amp_2015_8_10 